\title{
SHARIA GOVERNANCE SEBAGAI SOLUSI MENGATASI PENGARUH NEGATIF KARAKTERISTIK SOSIAL-POLITIK TERHADAP PENGUNGKAPAN I-CSR BANK SYARIAH
}

\section{SHARIA GOVERNANCE AS A SOLUTION TO OVERCOME THE NEGATIVE EFFECT OF SOCIAL-POLITICAL CHARACTERISTICS ON ISLAMIC BANK'S I-CSR DISCLOSURES}

\author{
Agus Maulana ${ }^{1 a}$ \\ 1aProgram Studi Akuntansi Fakultas Ekonomi dan Bisnis, Universitas Pembangunan Nasional \\ Veteran Jakarta, Jl. RS Fatmawati Raya, Pondok Labu, Jakarta Selatan 12450 e-mail: \\ agus.maulana@upvnj.ac.id.
}

\begin{abstract}
This study aims to examine the influence of socio-political characteristics on the Islamic Corporate Social Responsibility (I-CSR) Disclosure of Islamic Bank, and to examine the moderation effect of sharia governance. The data used are 52 annual reports of Islamic banks from 13 countries during the 2014-2016 period. Socio-political character is proxied by the value of Public Right and Civil Liberties (PRCL), while disclosure of I-CSR is measured by content analysis based on the I-CSR disclosure index developed based on AAOIFI standards. Statistical testing uses the FGLS method with Moderated Regression Analysis (MRA) analysis. The results of this study indicate that the average disclosure of ICSR of Islamic banks is still relatively low at around $44 \%$, but tends to show an increasing trend from year to year. Hypothesis testing results show that the socio-political characteristics affect the level of disclosure of I-CSR. Further testing shows sharia governance acts as a pure moderator.
\end{abstract}

Key words: Islamic Bank, Socio-Political Context, Islamic Corporate Social Responsibility.

\begin{abstract}
ABSTRAK
Penelitian ini bertujuan untuk menguji pengaruh karakteristik sosial politik terhadap tingkat pengungkapan Islamic Corporate Social Responsibility (I-CSR), dan menguji apakah mekanisme sharia governance dapat memoderasi pengaruh dari karakteristik sosial politik terhadap pengungkapan I-CSR bank syariah. Data yang digunakan yaitu laporan tahunan 52 Bank syariah dari 13 negara selama periode 2014-2016. Karakter sosial politik diproksikan dengan nilai Public Right and Civil Liberties (PRCL), sedangkan pengungkapan I-CSR diukur dengan analisis konten berdasarkan indeks pengungkapan I-CSR yang dikembangkan berdasarkan standar AAOIFI. Pengujian statistika menggunakan metode FGLS dengan metode analisis Moderated Regression Analysis (MRA). Hasil penelitian ini menunjukan bahwa rata-rata pengungkapan I-CSR bank syariah masih relatif rendah yaitu sekitar 44\%, namun cenderung menunjukan tren yang meningkat dari tahun ke tahun. Hasil pengujian hipotesis menunjukan bahwa karakteristik sosial politik yang diproksikan dengan nilai PRCL berpengaruh terhadap tingkat pengungkapan I-CSR. Pengujian lebih lanjut menunjukan sharia governance berperan sebagai pure moderator.

Kata kunci: Bank Syariah, Konteks Sosial Politik, Islamic Corporate Social Responsibility.
\end{abstract}

Agus Maulana. 2020. Sharia Governance Sebagai Solusi Mengatasi Pengaruh Negatif Karakteristik Sosial-Politik Terhadap Pengungkapan I-CSR Bank Syariah. Jurnal Nisbah 6 (1): 1-14. 


\section{PENDAHULUAN}

Seiring berkembangnya literatur dalam bidang CSR, penelitian di bidang ekonomi dan keuangan syariah mulai mengembangkan CSR dari perspektif Islam yang dikenal dengan istilah Islamic Corporate Social Responsibility (I-CSR) (Khurshid, Al-Aali, Soliman, \& Amin, 2014). Munculnya konsep I-CSR merupakan sebuah ide yang untuk mengakomodasi karakteristik unik dari lembaga keuangan syariah yang berbeda dengan lembaga keuangan konvensional. Konsep CSR konvensional didasarkan pada prinsip triple bottom line yaitu ekonomi, sosial, dan lingkungan (people, planet, profit). Sedangkan konsep I-CSR terdiri tiga aspek yaitu ekonomi, sosial, dan spiritual (Haniffa \& Cooke, 2002; Khurshid et al., 2014). Aspek spiritual berkaitan dengan tanggung jawab bank syariah untuk menjamin bahwa layanannya telah telah patuh pada prinsip syariah (sharia compliance).

Berdasarkan literatur yang berkembang, selain dipengaruhi oleh faktor internal perusahaan, tingkat pengungkapan juga dipengaruhi oleh faktor kontekstual seperti lingkungan dan kondisi sosial politik (Farook et al., 2011; Fifka \& Pobizhan, 2014; Mitchell Williams, 1999). Menurut Mitchell Williams (1999), tingkat pengungkapan dipengaruhi secara signifikan oleh kebudayaan (uncertainty avoidance and masculinity), sistem politik, dan sipil. Pada kondisi sosial politik yang cenderung represip, suatu perusahaan menghadapi tekanan sosial yang rendah sehingga pengungkapan tanggung jawab sosialnya menjadi rendah (Farook et al., 2011). Oleh karena itu, perusahaan yang berada di negara yang relatif terbuka dan bebas lebih cenderung mengungkapkan informasi I-CSR yang lebih banyak untuk tujuan melegitimasi kegiatan perusahaannya.

Efek kondisi sosial politik terhadap rendahnya tingkat pengungkapan I-CSR bank syariah merupakan efek yang tidak terhindarkan, karena merupakan faktor bawaan bank syariah tersebut. Oleh karena itu, penelitian ini mencoba menguji apakah mekanisme tata kelola syariah (sharia governance) dapat memoderasi pengaruh kondisi sosial politik terhadap tingkat pengungkapan I-CSR bank syariah. Tata kelola dalam lembaga keuangan syariah dikenal dengan istilah sharia governance karena menerapkan Dual governance System yang direpresentasikan oleh adanya Dewan Pengawas Syariah (DPS).

DPS berperan sebagai badan independen dalam internal bank syariah. DPS berfungsi memastikan kepatuhan dari proses bisnis bank syariah terhadap hukum Islam agar nasabah terhindar dari riba (Abu-Tapanjeh, 2009). Selain itu, DPS menjalankan fungsi pengendalian internal dalam lembaga keuangan syariah yang bertugas untuk mengkaji dan mengawasi kegiatan dan kebijakan bank syariah (Garas \& Pierce, 2010).

Penelitian ini mencoba menghasilkan beberapa kontribusi terhadap kajian di bidang bank dan lembaga keuangan syariah. Kontribusi pertama, penulis menggunakan data yang lebih besar dari penelitian sebelumnya, dengan cakupan data yang lebih besar diharapkan akan menghasilkan data yang lebih variatif, hasil yang lebih kokoh (robustness), dan dapat digeneralisasi secara lebih luas.

Kedua, penelitian ini mencoba menggunakan faktor mekanisme sharia governance untuk mengetahui apakah berperan sebagai faktor moderator, pure moderator, atau tidak berperan sama sekali. Ketiga, penelitian ini menggunakan indeks pengungkapan CSR berdasarkan standar AAOIFI yang terbaru yang diambil dari Governance Standard No 1 and Governance Standard No 7. Indeks pengungkapan I-CSR ini dibagi menjadi 2 komponen utama yaitu pengungkapan syariah (Sharia Disclosure Index) dan pengungkapan sosial (Social Disclosure Index). Dengan dua komponen ini diharapkan lebih merepresentasikan 
akuntabilitas bank syariah yang sesuai dengan usulan penelitian-penelitian sebelumnya.

\section{MATERI DAN METODE}

\section{Pengungkapan Islamic Corporate Social Responsibility (I-CSR)}

Pengungkapan tanggung jawab bank syariah terkait kepatuhan syariah dan akuntabilitas sosial merupakan isu yang kritis karena menyangkut kredibilitas bank syariah tersebut (Lewis, 2001; Maali, Casson, \& Napier, 2006). Selain karena tuntutan bahwa bank syariah harus memastikan produknya telah sesuai dengan syariah Islam, pengungkapan informasi yang benar juga diperintahkan oleh Allah melalui Al-Quran (2:42), “...dan janganlah kamu menyembunyikan kebenaran, sedang kamu mengetahuinya". Oleh karena itu, bank syariah menghadapi risiko reputasi jika gagal memenuhi ekspektasi stakeholder dalam mengungkapkan informasi kepatuhan syariah dan tanggung jawab sosialnya.

Dalam bidang kajian perbankan syariah, pengungkapan informasi kepatuhan syariah dan tanggung jawab sosial dikenal dengan istilah Islamic Corporate Social Responsibility (I-CSR), atau Islamic Social Reporting (Khurshid et al., 2014). Konsep I-CSR merupakan pengembangan dari konsep CSR yang digunakan dalam kajian perusahaan secara umum. Sudut pandang CSR adalah prinsip triple bottom line yaitu ekonomi, sosial, dan lingkungan (people, planet, profit). Sedangkan konsep I-CSR terdiri dari tiga aspek yaitu ekonomi, sosial, dan spiritual (Haniffa \& Cooke, 2002). Aspek spiritual dalam kajian I-CSR berkaitan dengan pengungkapan tanggung jawab bank syariah terhadap proses penjaminan produk dan layanannya agar sesuai dengan prinsip syariah.

Landasan tentang pengungkapan ICSR secara umum dijelaskan dalam tiga teori yaitu Teori Stakeholder, Teori Legitimasi, Teori Agensi, dan Teori
Signalling (Clarkson, 1995; Hahn \& Kühnen, 2013). Berdasarkan teori legitimasi, pengungkapan I-CSR merupakan salah satu aksi perusahaan untuk melegitimasi bahwa kegiatan usahanya telah patuh hukum dan sesuai dengan norma sosial yang disepakati oleh masyarakat (Deegan, 2002). Perusahaan dianggap perlu mengungkapkan informasi tentang kegiatannya agar dapat diterima oleh masyarakat.

Berdasarkan teori stakeholder, perusahaan perlu mendapat dukungan dari para pemangku kepentingan untuk bisa berhasil mencapai tujuannya (Clarkson, 1995). Pemangku kepentingan tersebut adalah pihak yang mempengaruhi dan dipengaruhi oleh perusahaan seperti pelanggan, karyawan, pemilik, pemerintah, regulator, dan masyarakat sekitar perusahaan. I-CSR merupakan aktivitas perusahaan yang berkaitan dengan pemenuhan tanggung jawab sosial perusahaan kepada para stakeholder perusahaan sehingga dengan itu perusahaan dapat mendapatkan dukungan dari stakeholdernya tersebut (Clarkson, 1995).

Dari sudut pandang teori signalling, pengungkapan I-CSR dianggap sebagai sinyal dari agent (manajer perusahaan) kepada principle (pemilik perusahaan) berkaitan dengan kinerja sosial perusahaan dan kinerja perusahaan untuk memenuhi kepatuhan terhadap prinsip syariah (Hahn \& Kühnen, 2013). Lebih jauh lagi, informasi yang diungkapkan oleh manajer perusahaan dapat mengurangi asimetri informasi sehingga ditafsirkan sebagai sinyal yang baik oleh pasar. Oleh karena itu, seorang manajer akan mempunyai insentif yang besar untuk menilai risiko kepatuhan perusahaannya terhadap prinsip syariah dan tanggung jawab sosial (Tsalavoutas, 2011).

\section{Hubungan Karakteristik Sosial-Politik dan Pengungkapan I-CSR}

Akuntabilitas sosial bank syariah salah satunya tercermin dari keterbukaan informasi terkait kegiatan I-CSR (El- 
Halaby \& Hussainey, 2015). Salah satu faktor penentu pengungkapan I-CSR adalah kondisi sosial politik dimana bank syariah itu berdiri (Grassa \& Gazdar, 2014; Farook et al., 2011). Menurut Mitchell Williams ( 1999), bank merupakan entitas yang beroperasi di lingkungan sosial politik yang berbeda-beda, maka pola interaksi dan dialog antara bank dengan stakeholdernya ditentukan oleh hubungan timbal balik antara hak dan kewajiban lingkungan tersebut.

Kondisi sosial politik suatu negara pada umumnya berbeda antara satu negara dengan negara lainnya tergantung bentuk negara dan undang-undang yang berlaku di negara tersebut. Ada negara yang kondisi sosial politiknya bebas dan terbuka seperti negara-negara di Benua Amerika dan Eropa, ada juga yang cenderung lebih represif dengan regulasi yang ketat seperti Korea Utara, China, negara-negara yang memiliki bentuk kerajaan seperti di Timur Tengah, dan lain sebagainya.

Menurut Gastil (1981) dalam kondisi sistem politik dan sipil yang represif, masyarakat/lembaga sosial yang ada dalamnya menjadi sulit menyuarakan keprihatinan terhadap perilaku organisasi yang tidak bertanggung jawab. Oleh sebab itu, organisasi atau entitas bisnis yang berada di lingkungan sosial politik yang represif akan menghadapi tekanan sosial yang lebih rendah (Mitchell Williams, 1999). Sebaliknya, bank syariah yang beroperasi di negara yang kondisi sosial politiknya terbuka akan menghadapi tekanan sosial yang tinggi karena stakeholdernya dapat lebih menyuarakan kepentingannya.

Berdasarkan literatur tersebut, maka dapat diambil suatu kerangka dasar hubungan antara kondisi sosial politik dengan pengungkapan I-CSR. Bank syariah yang berada di negara yang bebas dan terbuka akan mengungkapkan informasi ICSR lebih banyak karena dorongan dari masyarakat dan kontrol organisasi sosialnya lebih tinggi. Sedangkan bank syariah yang ada di negara dengan sistem sosial politik yang cenderung represif (terkekang), mengungkapkan I-CSR lebih sedikit kontrol sosial dari stakeholder dan organisasi sosialnya lebih rendah. Berdasarkan landasan literatur tersebut, maka hipotesis pertama dari penelitian ini adalah

H1: Semakin represif kondisi sosial politik di satu negara, maka tingkat pengungkapan I-CSR bank syariah $d i$ negara tersebut semakin rendah

\section{Peran Sharia Governance dalam Memoderasi Hubungan antara Karakteristik Sosial Politik dengan Pengungkapan I-CSR.}

Bank syariah menerapkan tata kelola yang unik dan berbeda dari tata kelola bank konvensional. Prinsip sharia compliance membuat tata kelolanya disebut tata kelola ganda (dual governance system), yaitu menerapkan sistem AngloAmerican dan sistem hukum Islam (Mersni \& Ben Othman, 2016). Dual governance system di bank syariah direpresentasikan oleh keberadaan DPS. Karena karakteristik unik dari tata kelola lembaga keuangan Islam, maka tata kelola bank dan lembaga keuangan syariah disebut dengan nama sharia governance (Puspitasari \& Muhammad, 2019).

DPS bekerja secara independen dan kedudukannya setingkat dengan Dewan Direksi dan Dewan Komisaris. Keberadaan DPS mewakili kepentingan dari nasabah yang berharap transaksi keuangannya bersifat halal (Abu-Tapanjeh, 2009). Dalam sistem pengendalian internal, DPS juga berperan mengawasi dan memastikan kebijakan bank telah patuh kepada prinsip syariah (Garas \& Pierce, 2010).

Berdasarkan standar Accounting and Auditing Organization for Islamic Financial Institutions (AAOIFI), Governance Standard Nomor 7 disebutkan bahwa banyaknya DPS di dalam lembaga keuangan syariah adalah tiga sampai lima orang. Farook et al. (2011) menemukan bahwa keberadaan DPS, jumlah DPS dalam 
satu lembaga, dan pendidikan doktoral dari DPS mempengaruhi tingkat pengungkapan di bank syariah. Begitu juga hasil penelitian Akhtaruddin (2005) yang menemukan bahwa jumlah DPS dapat mempengaruhi tingkat pengungkapan bank syariah. Dilihat dari sudut pandang Teori Agensi, semakin banyak dewan pengawas syariah yang memiliki keahlian di bidang tertentu maka fungsi monitoring dari dewan tersebut akan semakin efektif (Singh, Mathur, \& Gleason, 2004). Selain dari jumlah DPS, adanya anggota DPS yang bekerja di beberapa bank syariah (cross membership) dianggap dapat meningkatkan transparansi informasi karena pengalaman dan pandangannya yang semakin luas (Farook et al., 2011).

Seperti yang dijelaskan pada poin sebelumnya, bank syariah yang ada di negara dengan sistem sosial politik yang cenderung represif maka akan mendapat pengawasan yang lebih lemah dari stakeholder dan masyarakat sehingga akuntabilitas sosial yang ditunjukan dengan keterbukaan informasi I-CSR menjadi rendah. Namun, dengan adanya peran DPS dalam bank syariah yang berfungsi sebagai pengawasan bank syariah maka pengawasan yang tadinya lemah menjadi lebih kuat. Berdasarkan landasan pemikiran tersebut makan hipotesis kedua dari penelitian ini adalah :

H2: Mekanisme Sharia Governance memoderasi pengaruh kondisi sosial politik terhadap tingkat pengungkapan ISR

\section{Data dan Sampel}

Penelitian ini menggunakan data 13 negara yang terdiri dari Qatar, Indonesia, Malaysia, Arab Saudi, UEA, Oman, Turki, Bahrain, Bangladesh, Kuwait, Pakistan, Yordania dan Mesir. Pemilihan sampel menggunakan purposive sampling dengan kriteria (1) Bank syariah yang menerbitkan laporan tahunan yang dapat diakses secara publik pada tahun 20142016, (2) Laporan tahunan tersebut diterbitkan dalam Bahasa Inggris atau Bahasa Indonesia. Pengungkapan I-CSR diperoleh dari laporan tahunan, skor PRCL diperoleh dari halaman website Freedom House (Freedom House Index, 2019).

\section{Pengembangan Indeks Pengungkapan I-CSR berdasarkan Standar AAOIFI}

Berdasarkan penelitian sebelumnya, pengukuran tingkat pengungkapan I-CSR menggunakan indeks yang berbeda-beda. Vinnicombe (2010) mengembangkan indeks berdasarkan AAOIFI yang terdiri dari empat dimensi yaitu a) Dewan Pengawas Syariah, b) pembiayaan Mudharabah, c) pembiayaan Murabahah, dan d) Zakat. Kemudian Sellami \& Tahari (2017) mengembangkan indeks berdasarkan IFRS 7 dan AAOIFI, sedangkan El-Halaby \& Hussainey (2016) menggunakan AAOIFI Governance Standard 1 (GS 1), GS 7, dan FAS 1.

Indek pengungkapan I-CSR dalam penelitian ini dikembangkan berdasarkan standar AAOIFI yaitu berdasarkan GS 1 dan GS 7. Kerangka pengembangan yang digunakan mengikuti El-Halaby \& Hussainey (2016). Pemilihan standar AAOIFI dipilih karena objek penelitian ini terdiri dari beberapa negara, sehingga perlu benchmark yang diakui secara internasional. Seperti yang ditunjukan pada Gambar 1, komponen pengungkapan I-CSR dalam indeks penelitian ini dibagi menjadi 2, yaitu sharia disclosure index dan social disclosure index. Secara keseluruhan indeks pengungkapan nya $\begin{array}{llll}\text { terdiri dari } & 72 & \text { item. }\end{array}$ 


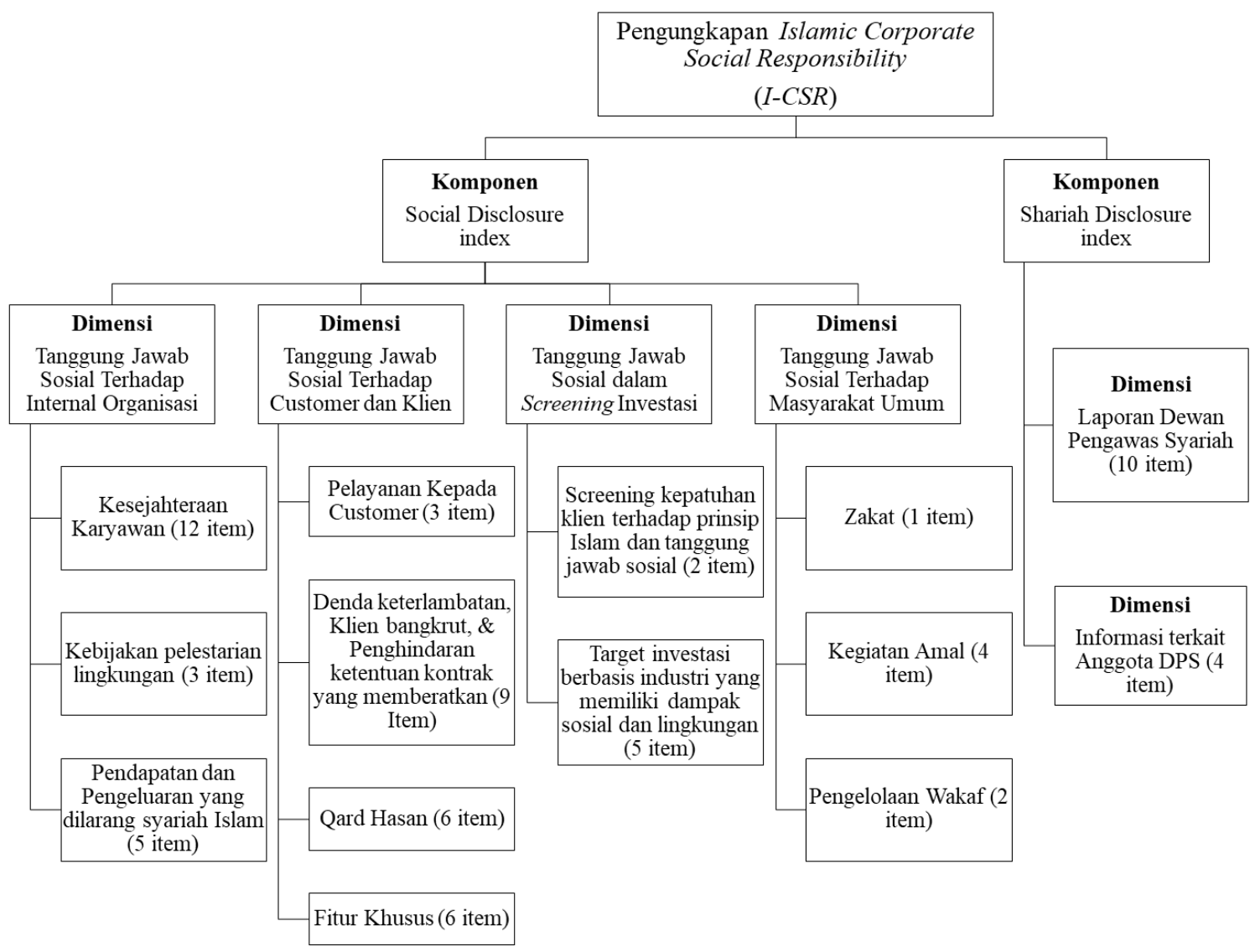

Gambar 1. Gambaran Komponen dan Dimensi Pengembangan Indeks I-CSR berdasarkan AAOIFI

Seperti yang ditunjukan Gambar 1, pengungkapan syariah terdiri dari 14 item yang isinya berkaitan dengan kepatuhan bank terhadap prinsip-prinsip syariah seperti Laporan Dewan Pengawas Syariah terkait hasil pengawasan dan penilaiannya terhadap aktivitas perusahaan, dan pengungkapan informasi terkait anggota DPS. Sedangkan pengungkapan sosial terdiri dari 58 item yang berkaitan dengan aktivitas CSR seperti Kesejahteraan karyawan, kebijakan pelestarian lingkungan, treatment terhadap pendapatan yang dilarang agama (riba), pelayanan kepada pelanggan, kegiatan amal, pengelolaan wakaf, dan tindakan dalam memastikan kepatuhan syariah dari klien.

\section{Pengukuran Variabel}

Variabel dependen yaitu tingkat pengungkapan I-CSR dikembangkan berdasarkan AAOIFI mengikuti cara ElHalaby \& Hussainey (2016). Pertama, dimensi utama ditentukan berdasarkan format pengungkapan CSR di Appendix
(E) Example of Disclosure and Presentation Formats (AAOIFI, 2015). Dari setiap dimensi tersebut diuraikan setiap itemnya dengan merujuk pada standar pengungkapan yang ditentukan oleh AAOIFI. Terkait dengan beberapa item umum seperti pengungkapan kebijakan perusahaan, item pengungkapan diambil dari penjelasan yang terdapat pada $C S R$ implementation standards yang ada dalam GS 7.

Pengukuran tingkat pengungkapan I-CSR dalam penelitian ini menggunakan analisis konten berbasis kode ordinal yaitu 1 jika diungkapkan dan 0 jika tidak diungkapkan (Guthrie \& Abeysekera, 2006). Perhitungan nilai pengungkapan secara keseluruhan dihitung berdasarkan rumus berikut ini:

$$
I C S R_{i t}=\frac{\sum_{t=1}^{n} \quad X_{i j t}}{N}
$$


$I C S R_{i t}$ adalah tingkat pengungkapan I-CSR bank $i$ pada tahun $t$. $\mathrm{X}_{i j t}$ adalah pengungkapan item $X$, pada bank syariah $i$, dimensi $j$, pada tahun $t$. Total pengungkapan dibagi dengan total item yaitu $\mathrm{N}$ atau 72 item. Tabel 1 menunjukan pengukuran rincian untuk pengukuran setiap varibel.

Tabel 1. Pengukuran Variabel

\begin{tabular}{|c|c|c|}
\hline Variabel & Simbol & Pengukuran \\
\hline \multicolumn{3}{|c|}{ Variabel Dependen } \\
\hline $\begin{array}{l}\text { Pengungkapan } \\
\text { Islamic } \\
\text { Corporate Social } \\
\text { Responsibility }\end{array}$ & $I C S R$ & $\begin{array}{l}\text { Konten analisis } \\
\text { menggunakan skoring } \\
1 \text { jika diungkapkan, } \\
\text { dan } 0 \text { jika tidak. Indek } \\
\text { pengungkapan I-CSR } \\
\text { dikembangkan } \\
\text { berdasarkan standar } \\
\text { AAOIFI (GS } 1 \text { and GS7) } \\
\end{array}$ \\
\hline \multicolumn{3}{|c|}{ Variabel Independen } \\
\hline $\begin{array}{l}\text { Karakteristik } \\
\text { Sosial Politik }\end{array}$ & $P R C L$ & $\begin{array}{l}\text { Nilai agregat Political } \\
\text { Rights and Civil } \\
\text { Liberties (PRCL) } \\
\text { dengan rentang skor } \\
\text { antara } 1 \text { (represif) } \\
\text { sampai } 100 \text { (bebas) } \\
\end{array}$ \\
\hline \multicolumn{3}{|c|}{ Variabel Moderasi } \\
\hline $\begin{array}{l}\text { Sharia } \\
\text { Governance }\end{array}$ & $I C G S$ & $\begin{array}{l}\text { Skoring dengan } \\
\text { kualifikasi DPS dengan } \\
6 \text { kriteria }\end{array}$ \\
\hline \multicolumn{3}{|l|}{ Variabel Kontrol } \\
\hline $\begin{array}{l}\text { - Ukuran } \\
\text { perusahaan } \\
\text { - Profitabilitas } \\
\text { - Kepemilikan } \\
\text { Asing }\end{array}$ & $\begin{array}{l}\text { SIZE } \\
\text { ROE } \\
\text { OWN }\end{array}$ & $\begin{array}{lr}\bullet & \text { Log dari } \\
\text { total aset } & \\
\bullet & \text { Return on } \\
\text { Equity } & \\
\bullet & \text { Presentase } \\
(\%) \text { kepemilikan asing } \\
>5 \% & \\
\end{array}$ \\
\hline
\end{tabular}

Variabel Independen dalam penelitian ini yaitu karakteristik sosial politik. Karakteristik sosial politik diproksikan dengan skor PRCL (Public Right and Civil Liberties) mengikuti penelitian Farook et al. (2011). Skor PRCL terdiri dari tiga skor yaitu skor PR (Public Right), skor CL (Civil Liberties), dan skor agregat PRCL. Skor PR dan CL masingmasing memiliki rentang nilai antara 1 sampai 14. Nilai 1 mewakili karakteristik sosial politik yang sangat bebas (freedom), sedangkan nilai 14 mewakili karakteristik sosial politik yang represif (repression). Untuk skor agregat rentang nilainya antara 1-100. Skor agregat 100 menunjukan kondisi sosial politik yang bebas dan terbuka (freedom), sedangkan skor 1 mewakili karakteristik sosial politik yang represif (repression). Penelitian ini menggunakan nilai skor agregat karena lebih mencerminkan nilai PRCL secara menyeluruh dan representatif. Skor PRCL diperoleh dari halaman website Freedom House (Freedom House Index, 2017) yang setiap tahunnya memberikan penilaian dan ranking terkait indeks PRCL.

Variabel Moderasi dalam penelitian ini adalah sharia governance yang dihitung secara kumulatif dari 6 karakteristik DPS seperti yang ditunjukan di tabel berikut ini:

Tabel 2. Pengukuran Kualifikasi DPS

\begin{tabular}{|c|c|c|}
\hline Karakteristik & Pengukuran & $\begin{array}{l}\text { Literatur } \\
\text { Pendukung }\end{array}$ \\
\hline $\begin{array}{l}\text { Jumlah } \\
\text { anggota DPS } \\
(N S S B)\end{array}$ & $\begin{array}{l}\text { nilai } 1 \text { jika } \\
\text { perusahaan } \\
\text { memiliki minimal } \\
3 \text { orang anggota } \\
\text { DPS, dan } 0 \text { jika } \\
\text { jumlah anggota } \\
\text { DPS kurang dari } 3\end{array}$ & $\begin{array}{l}\text { Farook et al. } \\
\text { (2011) } \\
\text { Akhatruddin } \\
\text { et al.(2009) }\end{array}$ \\
\hline $\begin{array}{l}\text { Reputasi DPS } \\
(R E P T)\end{array}$ & $\begin{array}{l}\text { Nilai } 1 \text { jika } \\
\text { minimal terdapat } \\
1 \text { anggota DPS } \\
\text { yang bereputasi. } \\
\text { DPS dianggap } \\
\text { memiliki reputasi } \\
\text { jika memiliki } \\
\text { posisi di komite } \\
\text { atau dewan } \\
\text { pengawas AAOIFI } \\
\text { dengan lama } \\
\text { keanggotaan } \\
\text { minimal } 1 \text { tahun. } \\
\text { Selain itu nilainya } \\
\text { 0. }\end{array}$ & $\begin{array}{l}\text { Farook et al. } \\
(2011) \\
\text { El-Halaby dan } \\
\text { Hussainey } \\
(2016) \\
\text { (Hussain \& } \\
\text { Mallin, 2003) }\end{array}$ \\
\hline $\begin{array}{l}\text { Keanggotaan } \\
\text { Silang (CROS) }\end{array}$ & $\begin{array}{lr}\text { Nilai } 1 \text { jika } \\
\text { terdapat minimal } \\
1 \text { orang anggota } \\
\text { DPS r yang } \\
\text { memiliki posisi } \\
\text { sebagai DPS juga }\end{array}$ & $\begin{array}{l}\text { Farook et al. } \\
(2011) \\
\text { El-Halaby dan } \\
\text { Hussainey } \\
(2016) \\
\text { (Haniffa \& }\end{array}$ \\
\hline
\end{tabular}




\begin{tabular}{|c|c|c|}
\hline & $\begin{array}{l}\text { di bank Islam lain. } \\
\text { Selain itu nilainya } \\
0\end{array}$ & Cooke, 2002) \\
\hline $\begin{array}{l}\text { Pendidikan } \\
\text { Ekonomi \& } \\
\text { Bisnis DPS } \\
(E C O N)\end{array}$ & $\begin{array}{l}\text { Nilai } 1 \text { jika } \\
\text { minimal ada satu } \\
\text { orang anggota } \\
\text { DPS yang } \\
\text { memiliki } \\
\text { kualifikasi } \\
\text { pendidikan S1 di } \\
\text { bidang Ekonomi } \\
\text { \& Bisnis, selain } \\
\text { itu nilainya } 0 .\end{array}$ & $\begin{array}{l}\text { Farook et al. } \\
(2011)\end{array}$ \\
\hline $\begin{array}{l}\text { Pendidikan } \\
\text { Syariah Islam } \\
\text { DPS }(S H A R)\end{array}$ & $\begin{array}{l}\text { Nilai } 1 \text { jika } \\
\text { minimal ada satu } \\
\text { orang anggota } \\
\text { DPS } \\
\text { memiliki } \\
\text { kualifikasi } \\
\text { pendidikan } \mathrm{S} 1 \mathrm{di} \\
\text { bidang hukum } \\
\text { atau syariah } \\
\text { Islam, selain itu } \\
\text { nilainya } 0 .\end{array}$ & $\begin{array}{l}\text { Farook et al. } \\
(2011)\end{array}$ \\
\hline $\begin{array}{l}\text { Pendidikan } \\
\text { Doktoral DPS } \\
(D O C T)\end{array}$ & $\begin{array}{l}\text { Nilai } 1 \text { jika } \\
\text { minimal ada satu } \\
\text { orang anggota } \\
\text { DPS yang } \\
\text { memiliki } \\
\text { kualifikasi } \\
\text { pendidikan S3, } \\
\text { selain itu nilainya } \\
0 .\end{array}$ & $\begin{array}{l}\text { Farook et al. } \\
(2011)\end{array}$ \\
\hline
\end{tabular}

Nilai sharia governance adalah nilai akumulasi dari 6 kriteria tersebut. Oleh karena itu, jika DPS suatu bank syariah memenuhi semua kualifikasi tersebut maka nilainya adalah 6. Jika tidak memenuhi sama sekali berarti nilainya 0 .

Variabel Kontrol dalam penelitian ini menggunakan Ukuran Aset (SIZE), Profitabilitas (ROE), dan Presentasi Kepemilikan Asing (OWN). SIZE diukur dari total aset perusahaan menunjukan hasil yang konsisten berpengaruh terhadap pengungkapan (Mitchell Williams, 1999). Dari sudut pandang teori legitimasi, perusahaan yang besar akan cenderung menghadapi banyak perhatian dari masyarakat luas (social exposure). Adanya perhatian ini menyebabkan perusahaan menjadi semakin terdorong melegitimasi aktivitasnya kepada publik (Patten, 1991).

\section{Model Penelitian}

Penelitian bertujuan untuk menguji pengaruh karakteristik sosial politik terhadap tingkat pengungkapan I-CSR, dan menguji apakah sharia governance dapat memoderasi hubungan kedua variabel tersebut. Data penelitian ini menggunakan unbalanced data panel dengan metode analisis statistika regresi Fixed Generalized Least Square (FGLS). Metode regresi FGLS ini digunakan untuk mengatasi masalah adanya autokorelasi dan heteroskedastisitas dari data yang sedang diuji. Analisis statistika penelitian ini menggunakan software Stata versi 14 .

Untuk menganalisis peran moderasi dari sharia governance digunakan teknik analisis data Moderated Regression Analysis (MRA). Analisis dilakukan dengan menggunakan tiga model berikut ini

$$
\begin{array}{rl}
I C S R_{i t}=\beta_{0}+ & \beta_{1} P R C L_{i t}+\beta_{2} S I Z E_{i t}+\beta_{3} R O E_{i t} \\
& +\beta_{4} O W N_{i t}+e \\
I C S R_{i t}=\beta_{0}+ & \beta_{1} P R C L_{i t}+\beta_{2} I C G S_{i t}+\beta_{3} S I Z E_{i t} \\
& +\beta_{4} R O E_{i t}+\beta_{5} O W N_{i t}+e \\
I C S R_{i t}=\beta_{0}+\beta_{1} & P R C L_{i t}+\beta_{2} I C G S_{i t} \\
& +\beta_{3} I C G S * P R C L_{i t}+\beta_{4} S I Z E_{i t} \\
& +\beta_{5} R O E_{i t}+\beta_{6} O W N_{i t} \\
& +e
\end{array}
$$

Jika variabel moderasi terindikasi sebagai variabel pure moderator, maka diuji kembali dengan model dibawah ini

$$
\begin{aligned}
I C S R_{i t}=\beta_{0}+ & \beta_{1} P R C L_{i t}+\beta_{2} I C G S * P R C L_{i t} \\
& +\beta_{3} S I Z E_{i t}+\beta_{4} R O E_{i t}+\beta_{5} O W N_{i t} \\
& +e
\end{aligned}
$$

Keterangan:

$I C S R=$ Tingkat Pengungkapan $I-$ 


$\begin{aligned} & \text { CSR } \\ \text { PRCL } & \text { Karakteristik Sosial Politik } \\ \text { ICGS } & \text { Skor Sharia Governance } \\ \text { ICGS*PRCL = } & \text { Interaksi Karakteristik } \\ & \text { Sosial Politik dengan skor } \\ & \text { Sharia Governance } \\ \text { SIZE } & \text { Ln total aset } \\ \text { ROE } & =\text { Return on Equity } \\ \text { OWN }= & \text { Presentase Kepemilikan } \\ & \text { Asing }>5 \%\end{aligned}$

HASIL DAN PEMBAHASAN

\section{Pengungkapan Islamic Corporate Social Responsibility di Berbagai Negara}

Dalam pembahasan pertama ini akan dipaparkan hasil analisis konten pengungkapan I-CSR bank syariah di beberapa negara.

Tabel 3 Rata-Rata Persentase Tingkat

Pengungkapan I-CSR di Berbagai

Negara

\begin{tabular}{|c|c|c|c|c|}
\hline a $\quad$ Negar & 2014 & 2015 & 2016 & $\begin{array}{l}\text { Rata- } \\
\text { Rata }\end{array}$ \\
\hline Arab Saudi & 27,78 & 33,33 & 33,33 & 31,67 \\
\hline Bahrain & 42,50 & 46,39 & 48,33 & 45,74 \\
\hline Bangladesh & 44,72 & 52,78 & 49,72 & 48,81 \\
\hline Indonesia & 41,04 & 44,33 & 50,00 & 45,24 \\
\hline Jordan & 50,93 & 53,70 & 56,25 & 53,30 \\
\hline Kuwait & 30,83 & 36,11 & 38,61 & 35,19 \\
\hline Malaysia & 44,44 & 48,89 & 50,56 & 47,96 \\
\hline Mesir & - & - & 31,94 & 31,94 \\
\hline Oman & 40,97 & 43,75 & 46,53 & 43,75 \\
\hline Pakistan & 52,31 & 56,48 & 57,41 & 55,40 \\
\hline Qatar & 35,42 & 37,15 & 38,89 & 37,15 \\
\hline $\begin{array}{l}\text { Turki } \\
\text { United Arab }\end{array}$ & 20,83 & 29,17 & 30,56 & 26,85 \\
\hline Emirates & 55,56 & 52,78 & 56,25 & 54,72 \\
\hline Rata-rata & $\begin{array}{r}40,7 \\
7 \\
\end{array}$ & $\begin{array}{r}44,6 \\
9 \\
\end{array}$ & $\begin{array}{r}46,8 \\
9 \\
\end{array}$ & 44,16 \\
\hline
\end{tabular}

Berdasarkan hasil konten analisis, negara dengan pengungkapan I-CSR tertinggi adalah Pakistan dan UAE (55\%), sebaliknya pengungkapan I-CSR terendah yaitu Turki (27\%). Ada beberapa negara yang lebih dominan mengungkapkan $I$ CSR pada dimensi tertentu, tetapi ada juga yang sama sekali tidak mengungkapkan aktivitas I-CSR nya. Jika dilihat rata-rata pengungkapan I-CSR dari tahun ke tahun menunjukan peningkatan $(2014=41 \%$; $2015=45 \% ; 2016=47 \%$ )

Hasil konten analisis secara keseluruhan menunjukan bahwa nilai rata-rata pengungkapan I-CSR bank syariah dari 13 negara adalah $(44,16 \%)$. Hasil penelitian ini lebih tinggi dari temuan Farook et al. (2011) yang menunjukan rata-rata sekitar $17 \%$ dan temuan El-Halaby \& Hussainey (2015) sekitar 26\%. Meskipun pengungkapan ICSR bank syariah masih relatif rendah, namun trend yang ada memperlihatkan adanya peningkatan pengungkapan I-CSR dari satu penelitian ke penelitian berikutnya. Bank syariah yang merupakan pemain baru di pasar keuangan global mungkin masih dalam tahap penyesuaian, ada beberapa aspek yang masih lemah diantaranya akuntabilitasnya (El-Halaby \& Hussainey, 2015). Namun seiring berjalannya waktu, industri keuangan syariah semakin berkembang dan menunjukan perbaikan dalam aspek akuntabilitas dengan menunjukan tingkat pengungkapan I-CSR yang semakin tinggi.

\section{Statistika Deskriptif}

Tabel 4 menunjukan hasil analisis statistika deskriptif dari variabel penelitian. Setiap variabel dideskripsikan berdasarkan jumlah observasi $(\mathrm{N})$, nilai minimal (MIN), nilai maksimal (MAX), dan standar deviasi (STD.DEV).

Tabel 4 Statistika Deskriptif

\begin{tabular}{llllll}
\hline VAR & N & MIN & MAX & $\begin{array}{l}\text { MEA } \\
\text { N }\end{array}$ & S.D \\
\hline ICSR & 148 & 18,06 & 68,06 & 6 & 11,28 \\
& & & & 39,7 & \\
PRCL & 148 & 10,00 & 65,00 & 0 & 18,17 \\
ICSG & 148 & 2,00 & 6,00 & 4,29 & 0,96 \\
& & & 90.58 & 8.50 & \\
SIZE & 148 & 54 & 9 & 3 & 13.894 .591
\end{tabular}




\begin{tabular}{llllll} 
ROE & 148 & $-0,49$ & 0,32 & 0,08 & 0,10 \\
OWN & 148 & 0,00 & 0,99 & 0,17 & 0,29 \\
\hline
\end{tabular}

Catatan: SIZE dalam ribuan Dollar (\$)

Dilihat dari aspek pengungkapan $I$ $C S R$, rata-rata tingkat pengungkapan masih relatif rendah yaitu sekitar $44 \%$. Hal ini menjadi kritik bagi para bankir dan regulator bank syariah untuk terus meningkatkan akuntabilitas sosialnya karena menurut beberapa penelitian menunjukan pengungkapan CSR juga berdampak terhadap nama baik bank syariah (Nurjanah \& Mulazid, 2018). Rentang nilai minimal (18\%) dan maksimal (68\%) yang berjarak cukup jauh menunjukan tingkat pengungkapan I-CSR sangat bervariasi.

Dilihat dari aspek karakteristik sosial politik, nilai terendahnya yaitu 10 yang menunjukan karakter negara yang represif, sedangkan nilai 65 menunjukan karakteristik sosial politik yang terbuka dan bebas. Kebanyakan dari negara ini adalah negara kerajaan yang berada di wilayah timur tengah seperti Arab Saudi, UAE, dan kuwait. Bentuk negara yang kerajaan, dimana pemimpin negara didasarkan pada keturunan keluarga kerajaan membuat karakteristik sosial politiknya cenderung tertutup dan represif.

\section{Hasil Analisis Regresi}

Tujuan penelitian ini adalah untuk menguji pengaruh karakteristik sosial politik terhadap tingkat pengungkapan ICSR bank syariah, dan menguji peran moderasi dari Sharia Governance terhadap hubungan kedua variabel tersebut. Tabel 5 (terlampir) menunjukan hasil analisis pengujian statistika regresi Fixed Generalized Least Square untuk mengetahui pengaruh karakteristik Sosial Politik (PRCL) terhadap tingkat Pengungkapan I-CSR. Spesifikasi model menunjukan nilai $\mathrm{Chi}^{2}$ 1762,92 dengan taraf signifikansi dibawah 1 persen, hasil ini menunjukan bahwa model 1 telah sesuai dan nilai estimasinya dapat diterima.
Nilai Koefisien PRCL di Model 1 menunjukan nilai 1,4591 dengan taraf signifikansi dibawah 5 persen. Nilai ini menunjukan bahwa karakteristik sosial politik berpengaruh terhadap tingkat pengungkapan I-CSR bank syariah. Berdasarkan pengujian statistika tersebut, maka hipotesis pertama $\left(H_{1}\right)$ terbukti dan diterima. Hasil ini sama dengan temuan Farook et al. (2011), sehingga menguatkan pendapat bahwa dalam kondisi sistem politik dan sipil yang represif maka masyarakat yang ada dalamnya menjadi sulit menyatakan keprihatinan terhadap perilaku organisasi yang tidak bertanggung jawab. Oleh sebab itu, organisasi atau entitas bisnis yang berada di lingkungan sosial politik yang represif akan menghadapi tekanan sosial yang lebih rendah (Mitchell Williams, 1999). Tekanan sosial yang rendah membuat bank syariah yang berada di negara represif menjadi tidak terdorong melakukan pengungkapan aktivitas I-CSR nya.

Tabel 6 (terlampir) menunjukan hasil pengujian statistika model 2 , yaitu model untuk menguji apakah sharia governance (ICGS) berpengaruh secara langsung terhadap tingkat pengungkapan I-CSR. Spesifikasi model 2 menunjukan nilai Chi $^{2}$ 1813,79 dengan taraf signifikansi dibawah 1 persen, hasil ini menunjukan bahwa model 2 telah sesuai dan nilai estimasinya dapat diterima. Nilai koefisien sharia governance (ICGS) menunjukan nilai 3,0749 dengan taraf signifikansi dibawah 5 persen. Artinya, mekanisme tata kelola syariah berpengaruh secara langsung terhadap tingkat pengungkapan. Keberadaan DPS dengan kualifikasi tertentu dapat membuat fungsi pengawasan menjadi lebih efektif.

Tabel 7 (terlampir) menunjukan hasil pengujian statistika model 3 , yaitu model untuk menguji apakah sharia governance (ICGS) berperan memoderasi pengaruh karakteristik sosial politik 
terhadap tingkat pengungkapan I-CSR. Spesifikasi model 3 menunjukan nilai $\mathrm{Chi}^{2}$ 1836,89 dengan taraf signifikansi dibawah 1 persen, hasil ini menunjukan bahwa model 3 telah sesuai dan nilai estimasinya dapat diterima. Nilai koefisien interaksi antara sharia governance (ICGS) dan karakteristik sosial politik (PRCL) menunjukan nilai 0,2036 dengan taraf signifikansi 0,187. Nilai ini menunjukan bahwa sharia governance tidak memoderasi pengaruh karakteristik sosial politik terhadap tingkat pengungkapan I-CSR. Begitu juga dengan nilai parsial ICGS dan PRCL dalam model 3 ini menunjukan tidak adanya berpengaruh yang signifikan. Oleh karena itu, untuk menguji apakah sharia governance merupakan murni pure moderator atau bukan, maka analisis dilanjutkan dalam model 4 .

Tabel 8 (terlampir) menunjukan hasil pengujian statistika model 4, yaitu model untuk menguji apakah sharia governance (ICGS) merupakan variabel pure moderator atau bukan. Spesifikasi model 4 menunjukan nilai $\mathrm{Chi}^{2}$ 1825,07 dengan taraf signifikansi dibawah 1 persen, hasil ini menunjukan bahwa model 4 telah sesuai dan nilai estimasinya dapat diterima. Nilai koefisien interaksi antara karakteristik sosial politik dengan sharia governance (PRCL*ICGS) menunjukan nilai 0,0607 dengan taraf signifikansi dibawah 5 persen. Berdasarkan hasil analisis tersebut, maka hipotesis dua $\left(\mathrm{H}_{2}\right)$ diterima dan menunjukan bahwa mekanisme sharia governance (ICGS) merupakan variabel pure moderator. Artinya, keberadaan DPS dengan kualifikasi tertentu dapat mengurangi pengaruh kondisi sosial politik yang represif sehingga mendorong bank syariah untuk lebih akuntabel dalam menjalankan bisnisnya.

\section{KESIMPULAN DAN IMPLIKASI}

Penelitian ini bertujuan menguji pengaruh karakteristik sosial politik terhadap tingkat pengungkapan I-CSR bank syariah, dan menguji peran moderasi dari sharia governance atas hubungan kedua variabel tersebut. Data yang digunakan yaitu data laporan tahunan bank syariah dari 13 negara. Hasil analisis pengujian statistika menunjukan adanya pengaruh positif signifikan dari karakteristik sosial politik yang diproksikan dengan nilai PRCL terhadap tingkat pengungkapan I-CSR. Hasil pengujian lebih lanjut juga menunjukan bahwa mekanisme sharia governance merupakan variabel pure moderator yang dapat memoderasi hubungan antara karakteristik sosial politik terhadap tingkat pengungkapan ICSR bank syariah. Hasil penelitian ini menguatkan pendapat bahwa semakin bebas kondisi sosial politik suatu negara, maka pengawasan terhadap bank syariah menjadi semakin ketat sehingga menjadi faktor pendorong bank syariah untuk melegitimasi aktivitasnya serta memenuhi ekspektasi stakeholdernya dengan memberikan pengungkapan aktivitas I-CSR lebih banyak. Selain itu, mekanisme sharia governance berperan mengatasi sistem pengawasan yang lemah terhadap bank syariah didalam kondisi sosial politik yang represif.

Implikasi dari penelitian ini yaitu terkait dengan pengungkapan I-CSR hasil analisis konten yang menunjukan tingkat pengungkapan I-CSR di beberapa negara masih relatif rendah. Oleh karena itu, bank syariah diharapkan dapat lebih meningkatkan akuntabilitas sosialnya dengan lebih terbuka mengungkapkan informasi terkait tanggung jawab sosial dan kepatuhan syariah dari operasionalnya. Adapun keterbatasan penelitian ini ada pada aspek pengukuran pengungkapan I-CSR yang didasarkan hanya pada laporan tahunan perusahaan 
sehingga memungkinkan adanya perbedaan dengan aktivitas nyata yang dilaksanakan bank syariah.

\section{DAFTAR PUSTAKA}

Accounting and Auditing Organization for Islamic Financial Institution. (2015). Corporate Social Responsibility Conduct and Disclosure for Islamic Financial Institutions (Governance Standard No. 7). AAOIFI, Bahrain.

Al-Qur'an. (2009). Al-Qur'an dan Terjemahannya, Departemen Agama RI. Jakarta : Sygma Examedia Arkanleema.

Abu-Tapanjeh, A. M. (2009). Corporate governance from the Islamic perspective: A comparative analysis with OECD principles. Critical Perspectives on Accounting. https://doi.org/10.1016/j.cpa.2007. 12.004

Akhtaruddin, M. (2005). Corporate mandatory disclosure practices in Bangladesh. International Journal of Accounting.

https://doi.org/10.1016/j.intacc.200 5.09.007

Brammer, S., Williams, G., \& Zinkin, J. (2007). Religion and attitudes to corporate social responsibility in a large cross-country sample. Journal of Business Ethics. https://doi.org/10.1007/s10551006-9136-z

Clarkson, M. E. (1995). A STAKEHOLDER FRAMEWORK FOR ANALYZING AND EVALUATING CORPORATE SOCIAL PERFORMANCE. Academy of Management Review. https://doi.org/10.5465/amr.1995.9 503271994
Deegan, C. (2002). Introduction: The legitimising effect of social and environmental disclosures - a theoretical foundation. Accounting, Auditing \& Accountability Journal. https://doi.org/10.1108/095135702 10435852

El-Halaby, S., \& Hussainey, K. (2015). The determinants of social accountability disclosure: Evidence from islamic banks around the world. International Journal of Business, 20(3), 202-223.

El-Halaby, S., \& Hussainey, K. (2016). Determinants of compliance with AAOIFI standards by Islamic banks. International Journal of Islamic and Middle Eastern Finance and Management, 9(1), 143-168. https://doi.org/10.1108/IMEFM-062015-0074

Ernst and Young. (2016). World Islamic Banking Competitiveness Report 2016. In Ernst and Young.

Fama, E. F., \& Jensen, M. C. (1983). Separation of Ownership and Control Separation of Ownership and Control. Journal of Law and Economics. https://doi.org/10.1086/467037

Farook, S., Kabir Hassan, M., \& Lanis, R. (2011). Determinants of corporate social responsibility disclosure: the case of Islamic banks. Journal of Islamic Accounting and Business Research, 2(2), 114-141. https://doi.org/10.1108/175908111 11170539

Fifka, M. S., \& Pobizhan, M. (2014). An institutional approach to corporate social responsibility in Russia. Journal of Cleaner Production. https://doi.org/10.1016/j.jclepro.20 
14.06.091

$\underset{\text { www.freedomhouse.org }}{\text { Freedom Index. }}$ (2017).

Garas, S. N., \& Pierce, C. (2010). Shari'a supervision of Islamic financial institutions. Journal of Financial Regulation and Compliance. https://doi.org/10.1108/135819810 11093695

Gastil, R. D. (1981). Freedom in the World 1981. New York: Freedom House.

Grassa, R., \& Gazdar, K. (2014). Law and Islamic finance: How legal origins affect Islamic finance development? Borsa Istanbul Review, 14(3), 158166.

https://doi.org/10.1016/j.bir.2014.0 5.001

Guthrie, J., \& Abeysekera, I. (2006). Content analysis of social, environmental reporting: what is new? Journal of Human Resource Costing \& Accounting. https://doi.org/10.1108/140133806 10703120

Hahn, R., \& Kühnen, M. (2013). Determinants of sustainability reporting: A review of results, trends, theory, and opportunities in an expanding field of research. Journal of Cleaner Production, 59, 5-21. https://doi.org/10.1016/j.jclepro.20 13.07.005

Haniffa, R. M., \& Cooke, T. E. (2002). Culture, corporate governance and disclosure in Malaysian corporations. Abacus.

https://doi.org/10.1111/14676281.00112

Hussain, S. H., \& Mallin, C. (2003). The dynamics of corporate governance in Bahrain: Structure, responsibilities and operation of corporate boards. Corporate Governance: An International Review. https://doi.org/10.1111/14678683.00322

Khurshid, M. A., Al-Aali, A., Soliman, A. A., \& Amin, S. M. (2014). Developing an Islamic corporate social responsibility model (ICSR). Competitiveness Review, 24(4), 258274. https://doi.org/10.1108/CR01-2013-0004

Lewis, M. K. (2001). Islam and accounting. Accounting Forum. https://doi.org/10.1111/14676303.00058

Maali, B., Casson, P., \& Napier, C. (2006). Social reporting by islamic banks. Abacus.

https://doi.org/10.1111/j.14676281.2006.00200.x

Mersni, H., \& Ben Othman, H. (2016). The impact of corporate governance mechanisms on earnings management in Islamic banks in the Middle East region. Journal of Islamic Accounting and Business Research. https://doi.org/10.1108/JIABR-112014-0039

Mitchell Williams, S. (1999). Voluntary environmental and social accounting disclosure practices in the AsiaPacific region: An international empirical test of political economy theory. International Journal of Accounting. https://doi.org/10.2469/dig.v30.n2. 655

Nurjanah, R., \& Mulazid, A. S. (2018). Pengaruh Kualitas Pelayanan dan Corporate Social Responsibility Terhadap Citra Perusahaan. Muqtasid: Jurnal Ekonomi Dan 
Perbankan Syariah, 9(1), 40. https://doi.org/10.18326/muqtasid. v9i1.40-53

Patten, D. M. (1991). Exposure, legitimacy, and social disclosure. Journal of Accounting and Public Policy. https://doi.org/10.1016/02784254(91)90003-3

Puspitasari, L. L., \& Muhammad, R. (2019). Perumusan Konsep Shariah Governance di Indonesia: Evaluasi Model Pengawasan Syariah di Sektor Perbankan. Muqtasid: Jurnal Ekonomi Dan Perbankan Syariah, 10(1), 1. https://doi.org/10.18326/muqtasid. v10i1.1-16

Sellami, Y. M., \& Tahari, M. (2017). Factors influencing compliance level with AAOIFI Financial accounting standards by Islamic banks. Journal of Applied Accounting Research, 18(1),
https://doi.org/10.1108/JAAR-012015-0005

Singh, M., Mathur, I., \& Gleason, K. C. (2004). Governance and performance implications of diversification strategies: Evidence from large U.S. firms. Financial Review.

https://doi.org/10.1111/j.07328516.2004.00086.x

Tsalavoutas, I. (2011). Transition to IFRS and compliance with mandatory disclosure requirements: What is the signal? Advances in Accounting, 27(2), 390-405. https://doi.org/10.1016/j.adiac.201 1.08 .006

Vinnicombe, T. (2010). AAOIFI reporting standards: Measuring compliance. Advances in Accounting, 26(1), 55-65. https://doi.org/10.1016/j.adiac.201 0.02 .009 


\section{LAMPIRAN}

Tabel 5. Analisis Statistik Moderated Regression Analysis - Model 1

\begin{tabular}{|c|c|c|c|c|}
\hline \multicolumn{5}{|c|}{$I C S R_{i t}=\beta_{0}+\beta_{1} P R C L_{i t}+\beta_{2} S I Z E_{i t}+\beta_{3} R O E_{i t}+\beta_{4} O W N_{i t}+e$} \\
\hline Variabel & Prediksi & Koefisien & $\begin{array}{c}\mathrm{t}- \\
\text { stattistic }\end{array}$ & Signifikansi \\
\hline Cons & & -145.4789 & -3.01 & $0.003^{* *}$ \\
\hline$P R C L$ & + & 1.4591 & 2.75 & $0.002^{* *}$ \\
\hline SIZE & + & 6.9790 & 4.33 & $0.000^{* * *}$ \\
\hline$R O E$ & + & 1.5571 & 1.36 & 0.806 \\
\hline$O W N$ & + & 3.8217 & 0.28 & 0.826 \\
\hline \multicolumn{2}{|c|}{$\begin{array}{l}\text { Jumlah Observasi } \\
\text { Wald-Chi } \\
\text { Prob }>\text { Chi }^{2}\end{array}$} & \multicolumn{3}{|l|}{$\begin{array}{l}148 \\
1762.92 \\
0.0000^{* * *}\end{array}$} \\
\hline \multicolumn{5}{|c|}{$\begin{array}{l}\text { Ket: *,**,*** masing-masing menunjukan signifikansi pada level at 0.10, } \\
0.05 \text { and } 0.01 \text { levels respectively }\end{array}$} \\
\hline
\end{tabular}

Tabel 6. Analisis Statistik Moderated Regression Analysis - Model 2

\begin{tabular}{|c|c|c|c|c|}
\hline Variabel & Prediksi & Koefisien & $\begin{array}{c}\mathrm{t}- \\
\text { stattistic }\end{array}$ & Signifikansi \\
\hline Cons & & -148.892 & -3.12 & $0.002^{* *}$ \\
\hline$P R C L$ & + & 1.4335 & 3.07 & $0.002^{* *}$ \\
\hline$I C G S$ & + & 3.0749 & 1.99 & $0.047^{*}$ \\
\hline SIZE & + & 6.6904 & 3.50 & $0.000^{* * *}$ \\
\hline$R O E$ & + & 1.8454 & 0.30 & 0.768 \\
\hline$O W N$ & + & 3.6083 & 0.21 & 0.833 \\
\hline \multicolumn{2}{|l|}{$\begin{array}{l}\text { Jumlah Observasi } \\
\text { Wald-Chi } \\
\text { Prob }>\text { Chi } \\
\end{array}$} & \multicolumn{3}{|l|}{$\begin{array}{l}148 \\
1813.79 \\
0.0000^{* * *} \\
\end{array}$} \\
\hline \multicolumn{5}{|c|}{$\begin{array}{l}\text { Ket: *, **, }{ }^{* * *} \text { masing-masing menunjukan signifikansi pada level at 0.10, } \\
0.05 \text { and } 0.01 \text { levels respectively }\end{array}$} \\
\hline
\end{tabular}

Tabel 7. Analisis Statistik Moderated Regression Analysis - Model 3

\begin{tabular}{|l|c|c|c|l|}
\hline \multicolumn{6}{|c|}{ ICSR $_{i t}=\beta_{0}+$} & $\beta_{1} P R C L_{i t}+\beta_{2} I C G S_{i t}+\beta_{2} P R C L * I C G S_{i t}+\beta_{3} S I Z E_{i t}$ \\
& $+\beta_{4} R O E_{i t}+\beta_{5} O W N_{i t}+e$ \\
\hline \multicolumn{6}{|c|}{ Variabel } & Prediksi & Koefisien & t- & Stattistic & Signifikansi \\
\hline Cons & & -110.458 & -1.98 & $0.047^{* *}$ \\
PRCL & + & 0.8008 & 1.20 & 0.230 \\
ICGS & + & -8.1101 & -0.94 & 0.346 \\
\hline
\end{tabular}




\begin{tabular}{|c|c|c|c|c|}
\hline $\begin{array}{l}\text { PRCL*ICGS } \\
\text { SIZE } \\
\text { ROE } \\
\text { OWN }\end{array}$ & $\begin{array}{l}+ \\
+ \\
+ \\
+\end{array}$ & $\begin{array}{l}0.2036 \\
6.4503 \\
1.7764 \\
3.4343 \\
\end{array}$ & $\begin{array}{l}1.32 \\
3.38 \\
0.29 \\
0.20 \\
\end{array}$ & $\begin{array}{l}0.187 \\
0.001^{* * *} \\
0.775 \\
0.840 \\
\end{array}$ \\
\hline $\begin{array}{l}\text { Jumlah Observasi } \\
\text { Wald-Chi } \\
\text { Prob }>C h i^{2}\end{array}$ & & $\begin{array}{l}148 \\
1836.89 \\
0.0000^{* * *}\end{array}$ & & \\
\hline
\end{tabular}

Tabel 8. Analisis Statistik Moderated Regression Analysis - Model 4

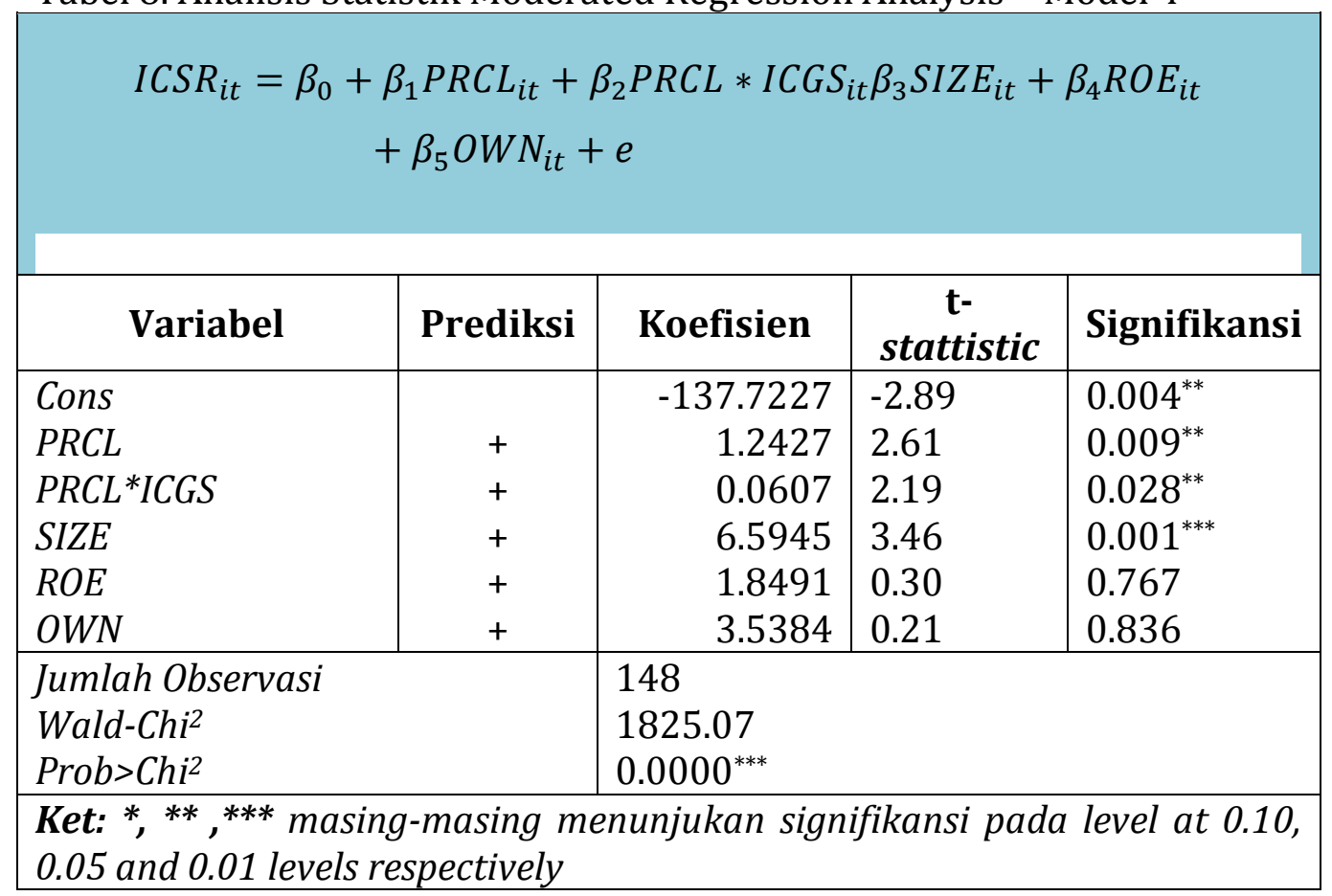

